\title{
Hernádi Mária
}

Pázmány Péter Katolikus Egyetem, Bölcsészet- és Társadalomtudományi Kar,

Tanárképző Intézet, Tanító- és Óvóképző Tanszék

\section{A jelenlét tapasztalata az Iskolában}

\section{Az Iskola a határon címú Ottlik-regényre reflektáló érzékenyebb} irások már egészen korán felfigyeltek arra, hogy a könyvben bemutatott történet veleje és tétje nem a külsó cselekmény, hanem a szereplók, elsốsorban Medve és Bébé belsó útja. Az elbeszélés idóbeli és narrációs struktúráját ezeknek a belsó utaknak az ivei határozzák meg, és az események elmesélésének nézópontja is azért rendhagyó, mert erre az útra fókuszál, s ebból a rendhagyó nézópontból fakadnak „az elbeszélés nehézségei”. Mert „nem igy telt velünk az idó. Nem cselekményszerúen, nem áttekinthetöen. A kézzelfogható valóságban éltünk, nem dicséretes eszmék. jelképei közt vagy kerek történetek absztrakcióiban." (Ottlik, 1993a. 144.) Nem utolsósorban ez az új nézópont hozza létre a még a külsó cselekményre fókuszáló Továbbélőkból (a regény ósváltozatából) az Iskolát.

A z említett belső utak nem azonosak sem a jellemfejlődéssel, sem pedig a személyiségfejlődéssel, bár nyilvánvalóan nem függetlenek tőlük, hiszen ezek az utak egyszerre feltételezik és eredményezik is az érettség egyre magasabb szintjeit. A regény ősváltozatának címe beszédes, hiszen a gyermek szereplők számára éppen az a kérdés, hogy a traumatikus hirtelenséggel és abszurditással megváltozott életkörülmények között hogyan lehet tovább élni. Ugyanerre utal a regény első kiadásának mottójául szolgáló Rilke-idézet: „Ki beszél itt győzelemről? Túlélni: ez minden.” A kérdés, hogy mi az, ami ezekben a regényszereplőkként megjelenő emberi lényekben tovább akar élni és túl tud élni. Egyszerübben: mi az, ami a megmaradásra törekszik bennük? Nyilvánvaló, hogy nem a jellemük és nem is a személyiségük, hiszen ezek - már csak amiatt is, mert tíz-tizenegy éves gyerekekről van szó - hatalmas változáson, transzformáción mennek keresztül, és egészen átalakulnak a történet végére.

Azt a részt, amit nem változó, szilárd tartalomként észlelnek magukban a szereplők, s ami egyben a megmaradásuk záloga, a vallások hagyománya léleknek, a jungiánus pszichológia pedig mély-énnek vagy mélymagnak nevezi. A lélek vagy mélymag az a „,belső várkastély” az emberben, ahol az a leginkább azonos önmagával: az ún. „igazi önmagunk", ami változatlan és romolhatatlan, ami megtartja és táplálja az embert, ám kegyelemszerü megtapasztalásához igen hosszú út vezet. ${ }^{1}$ A lélek vagy mélymag mellett a jungi személyiségmodellben a persona, a szerep-személyiség az énnek az a ,homlokzata”, amellyel a külvilág felé fordul, igazán mély találkozásai és kapcsolódásai mégis a mélymagot érintik. A mély-ént vagy lelket egyszerre észleljük legbelső valóságként

${ }^{1}$ Carl Gustav Jung (1993) nem véletlenül tartja az individuációs folyamat csúcspontjának a mély-én megtapasztalását és tudatosulását. 
és szabadságot biztosító, magasabb nézőpontként: e kettőnek felel meg Ottliknál az „allúvium” mint legmélyebb réteg ${ }^{2}$, illetve az ingyen mozi elméleten belül a „Néző-én” mint felettes nézőpont metaforája.

Az Iskola-szakirodalom által egyöntetüen a „,belső szabadsághoz” vezető útnak nevezett folyamat nem más, mint a lélek útja önmaga megtapasztalása felé, amelynek gyümölcsei a gyötrelmes élethelyzeten való felülemelkedés és az abból való szabadulás. Mártonffy Marcell (1998) szerint „,egyszerre beszélhetünk összefogással megszerzett, szemlélődéssel felismert, véletlenszerüen megtapasztalt, érlelődés útján kialakult, kegyelmi ajándékként megkapott, esetleg kiválasztottság folytán eleve létezó - predestinált - szabadságról." (Kiemelés az eredetiben) A szabadság itt felsorolt jelzői éppúgy egyszerre igazak arra a belső útra is, melynek során a lélek önmagára ébred. A regény fejezetcímeiben megjelenő Szent Pál-i mondat azonban, amely a regény önértelmezésének is tekinthetö, a felsoroltakból a „kegyelmi ajándékként megkapott” jelzőt hangsúlyozza és emeli ki, mintha ez tenné lehetővé az összes többit.

Ennek a felszabadulást hozó belső változásnak, illetve az én kettősségének szemléltetésére alkotta meg a trappista szerzetes, teológus és költö, Thomas Merton (2011. 29-32.; 2008. 42-48.) az „Igaz Én” és a „Hamis Én” fogalmát, amit ő maga „,belső” és „külső” énnek is nevezett. A fogalom a kontempláció, vagyis a szemlélődés vallásos hagyományát értelmező könyveiben tünik fel. A témában megjelent későbbi szakirodalom elsősorban az „igaz én - hamis én” terminológiáját veszi át Mertontól, de a „Nagy Én” és „Kis Én” kifejezéseket is használja ugyanerre (ld. pl. Rohr, 2013, 2014). Fontos, hogy mindez semmiképpen sem a személyiség két részre osztását, hanem az én kétféle szemléletét jelenti.
Azt a részt, amit nem változó, szilárd tartalomként észlelnek magukban a szereplók, s ami

egyben a megmaradásuk záloga, a vallások hagyománya léleknek, a jungiánus pszichológia pedig mély-énnek vagy mélymagnak nevezi. A lélek vagy mélymag az a ,belsó várkastély" az emberben, ahol az a leginkább azonos önmagával: az ún. „igazi önmagunk”, ami változatlan és romolhatatlan, ami megtartja és táplálja az embert, ám kegyelemszerü megtapasztalásához igen hoszszú út vezet. A lélek vagy mélymag mellett a jungi személyiségmodellben a persona, a szerep-személyiség az énnek az a „homlokzata”, amellyel a külvilág felé fordul, igazán mély találkozásai és kapcsolódásai mégis a mélymagot érintik. A mély-ént vagy lelket egyszerre észleljük legbelsố valóságként és szabadságot biztositó, magasabb nézópontként: e kettónek felel meg Ottliknál az „allúvium" mint legmélyebb réteg, illetve az ingyen mozi elméleten belül a „Nézó-én” mint felettes nézópont metaforája.

2 „Csak azt tudom, hogy van egy nagyon mély lerakódás a létezésünk alján, a második vagy legfeljebb harmadik réteg lehet alulról számítva, ami már végleges és változhatatlan, ahol már nem mozdul az életünk, tehát rossz szó rá, hogy lelassít, hiszen egyáltalán mozdíthatatlan és befejezett. Erős és szilárd tartalom ez az emberben, és nem valamilyen szomorú vagy halott dolog, sőt bizonyos tekintetben éppen ez él igazán, ez az, amit létezésünk folyamán létrehoztunk, amit életre hívtunk életünk anyagából. A többi és a további, a fedélzet rengése-ingása, a külsőbb rétegek, mint ez a mai civil életünk, már könnyü, és csak játék, maradék nyári nagyvakáció." (Ottlik, 1993a. 17-18.) 
Richard Rohr ferences szerzetes és kortárs lelkiségi író így határozza meg az önmagát érzelmeivel, gondolataival, valamint közösségi szerepeivel azonosító Kis Ént (más szóval a Hamis Ént, a Külső Ént vagy personát): „Amikor a Hamis Én kifejezést használom, azt az ént értem rajta, amelyet létrehozunk és magunkévá teszünk, hogy megtaláljuk identitásunkat a világban - a munkánkat, a hivatásunkat, a vallásunkat, a kultúránkat, a társadalmi helyzetünk elemeit. A Hamis Én itt nem azt jelenti, hogy rossz, hanem csak azt, hogy külső, múlékony, változó. Valamennyiünknek van Hamis Énje - szükségünk van rá, hogy élni tudjunk a világban. Az Igaz Én az, aki objektíven vagyunk Istenben. [...] Nem saját személyiségünk, választásaink, tapasztalataink révén hozzuk létre, nem lehet elöállítani vagy megalkotni. Legbelső lényegünket jelenti." (Rohr, 2014, fülszöveg) Az énnek ehhez a - kontemplatív hagyományban adott - kétfelől szemléléséhez egészen hasonló Ottlik ,ingyen mozi” metaforája, amit teljes részletességgel a Budában fejt ki. Ez az ottliki lét-metafora a személyiséget Néző- és Szereplő-részre osztja szét, amelyek az életet szemlélő és az életben cselekvő énnek feleltethetők meg: „Világra jöttél, egy vadidegen helyre, amihez semmi közöd. Peregni kezdett neked egy ingyen mozi, ahol néző vagy. A mozinak egy kicsike része azonban saját tested, $\mathrm{s}$ mivel ez az egyetlen olyan speciális darabkája, amivel kapcsolatod van, ezt is önmagadnak nevezed. De ez a második számú én már szereplöje az ingyen mozinak, a vadidegen világnak, ahol minden esetleges, és független néző voltodtól. Itt szereplők vagyunk, rabok, nem választhatunk [...] A néző pedig szabad. Nem lehet rabbá tenni egyáltalán."
Az énnek ehhez a - kontemplativ hagyományban adott - kétfelól szemléléséhez egészen hasonló Ottlik „ingyen mozi” metaforája, amit teljes részletességgel a Budában fejt ki. Ez az ottliki lét-metafora a személyiséget Nézó- és Szereplö-részre osztja szét, amelyek az életet szemléló és az életben cselekvó

énnek feleltethetôk meg: „Világra jöttél, egy vadidegen helyre, amihez semmi közöd.

Peregni kezdett neked egy ingyen mozi, ahol nézó vagy. A mozinak egy kicsike része azonban saját tested, s mivel ez

az egyetlen olyan speciális darabkája, amivel kapcsolatod van, ezt is önmagadnak nevezed. De ez a második számú én már szereplóje az ingyen mozinak, a vadidegen világnak, ahol minden esetleges, és független nézó voltodtól. Itt szereplók vagyunk, rabok, nem választhatunk [...] A nézó pedig szabad. Nem lehet rabbá tenni egyáltalán." (Ottlik, 1993b. 18-19.)

Ottlik, 1993b. 18-19.)

Hermányi Gabriella szerint a katonaiskolai években átélt szabadságvesztés valójában éppen a kontemplatív idő teljes és hosszú távú hiánya miatt - a Néző-én visszahúzódását és az énkép Szereplő Énné redukálódását jelenti, ami pedig a rabsággal és kiszolgáltatottsággal egyenlő. Az ezt az időszakot ábrázoló Iskola a határon szereplőinek belső fejlődése nem más, mint a Nézö-én visszaszerzéséért folytatott küzdelem, amely a katonaiskolai évek végére megvalósul, s mint valóságos szabadulás realizálódik (Hermányi, 2012).

A szabadulás tehát nem más, mint a Nézö-énbe való hazatalálás, amely, bár hoszszú lelki folyamat előzi meg, lényegében mégis egyetlen pillanat müve. Ami pedig ennek a racionálisan nem magyarázható, hirtelen nézőpontváltásnak, lelki ,áttörésnek” a pillanatát közvetlenül megelőzi, pontosabban lehetővé teszi azt és teret ad neki, az 
feltevésünk szerint mindig a tiszta jelenlét tapasztalata, az „itt és most” kivételesen intenzív észlelése, amely a háborgó elme és a zaklatott érzelmek káoszából a valóságba vezet vissza. A jelenlét, a mindenkori „van”, a csupasz létezés tapasztalata a regényben az érzékszervi észleléshez való visszatéréssel realizálódik, nyelvileg pedig a természeti és tárgyi környezet leírásaiban fejeződik ki, beleértve az emberi miliőt és a saját test észlelését is. A tárgyias észleleteket rögzítő, „listázó” leírások a regény előrehaladtával egyre gyakrabban fordulnak elő, ezzel is jelezve a jelenlét pillanatainak sürüsödését, amelyek a Néző-énbe való hazatalálás és a szabadulás útjelzői. A jelenlét pillanataiban mintha hirtelen csend támadna, mivel az érzelmek és gondolatok elhallgatnak, s átadják a helyüket a csendben feltáruló valóságnak. Egy ilyen feltárulásnak lehetünk tanúi Bébé egy különleges hajnali pillanatának ábrázolásában:

Kikönyököltem az egyik nyitott ablakon. Öt óra múlt, s szerda reggel volt, november hetedike. Néhány gyenge fényü körte égett a végtelen hosszú folyosón, ahol egyedül könyököltem egy ablakban. Itt is lógott néhány kép az ablakok közt, régi tábornokok, Radetzky, Savoyai Jenő. Az épület mögötti kopaszodó fákat inkább érezni lehetett, mint látni a vak éjszakában. A hűvös, hajnali levegőtől végigborzongtam. Kiegyenesedtem, és zsebre vágtam a két kezemet. Kint is, bent is aludt az egész világ, csönd volt, sötétség, a folyosó elhagyatott; mégis, mintha messziröl a szél zúgását hallanám, dúdolni kezdtem magamban hang nélkül valami indulófélét. Öt perc múlva ébresztö, vége szakad magányomnak, jelentkeznünk kell Schulzénál, és kezdődik újra a tánc. Nem bántam. Mert addig is békesség fogott el, elmondhatatlan, újfajta nyugalom, s nem is kellett jól megjegyeztem ezt az érzést, tudtam, hogy úgysem veszítem el többé. (Ottlik, 1993a. 224.)

Ugyanígy a jelenvaló észleletei kerülnek előtérbe Medve számára a szökésének abban a megmagyarázhatatlan, fizikai és lelki értelemben is fordulatot jelentő pillanatában, amikor a maga elött rugdosott konzervdoboz nyomában egyszer csak elindul visszafelé, vissza az iskolába, ahonnan néhány órával korábban megszökött:

Megrúgta a fa tövében elakadt konzervdobozt, és ment utána lefelé. Hátrahajlította a nyakát, hogy a könnyeit egy kicsit visszatartsa; így baktatott tovább, nem látva egyebet, mint a könnyeinek és a felszakadozó ködöknek kettős fátyolán át az ólomszürke eget. A lassan-lassan betörő reggeli világosságban némán füstölgött a kis völgy. (Ottlik, 1993a. 247.)

Az ,itt és most” valóságát feltáró jelenlét tiszta pillanatainak nyomában váratlan és megmagyarázhatatlan nyugalom támad. Ezt éli át Medve a szökése utáni éjszakán a fogdában: „A fáradtságtól időnként el-elszenderedett, s ahogy egyre kietlenebb, egyre kétségbeesettebb lelkiállapotban riadt fel újra meg újra, Isten tudja, hányadik felébredéskor egyszerre csak békesség fogta el." (Ottlik, 1993a. 283.) Nem sokkal ezután a betegszobában ismétlődik ez a tapasztalat: „Ismeretlen, lágy nyugalom volt ez.” (Ottlik, 1993a. 284.)

Ahogy már az idézett részekből is kitünhetett, a jelenlétre ébredés útja más Bébé, és megint más Medve számára. Ennek oka elsősorban az eltérő karakterük: kisfiúként Bébé higgadtabb, Medve inkább érzelemvezérelt. Medvére jellemző egy korának megfelelö, mégis kivételes gondolati érettséget mutató idealizmus ${ }^{3}, \mathrm{~s}$ az ebből magyarázható érzékenység az emberi közösségek minden igazságtalan és hamis müködésével szemben.

3 V. ö.: „...a világ mégis sokkal különb hely, az élet mégis nagyszerübb dolog, mint amilyennek józan ésszel látszik.”(Ottlik, 1993a. 173.) 
Intellektuális habitusára utal elmélkedésre való hajlama, s a valóság állandó értelmezésére irányuló belső kényszere. Bébé ezzel szemben közelebb van a földhöz, tovább megőrzi a gyermekekre jellemző realitásérzékét, a tárgyi valóságra irányuló éber kíváncsiságát. A közösségben és társas viszonyaiban óvatosabb, józanabb, hamarabb átlátja a hatalmi viszonyokat, s ezek közt a saját lehetöségeit. Könnyebben elfogadja a valóságot, mint Medve, alapjában is békésebb, nyugodtabb természetü. Eltérö karakterük ellenére mindkettőjükre egyformán jellemző az a kivételes érzékenység, amely azonnal jelzi az élethelyzetekben és viszonyokban megjelenő hamisságot, fonákságot és álságos attitüdöt, ebből fakad az, hogy mindketten képtelenek a hazugságra és önmaguk becsapására, de mások által sem manipulálhatók. Viselkedésük és gondolkodásmódjuk közös jellemzője a becsületesség és egyfajta gyermeki tisztaság, s bár Bébé talán kevésbé érzelmes, ugyanaz a szeretetéhség él mindkettőjükben.

A jellemrajzból már kikövetkeztethető, hogy a jelenlétre ébredéshez, a valóság észleléséhez és a szabaduláshoz Medve számára nehezebb út vezet. „M. nézte az eget, és látta is, amit néz. Közel kilencszázszor fog még így leszállni a nap az Alpok nyúlványai mögé, de ő soha többé, vagy legalábbis rettenetesen sokáig nem fogja látni, amit néz." (Ottlik, 1993a. 41.) - olvashatjuk a bevonulás napjának leírásában. Amikor később sorozatosan igazságtalan és méltatlan helyzetekbe kerül, az érzelmei elborítják, s el is takarják előle a valóságot: „Tehetetlenség, vágy és gyülölet, megalázottság és gőg, kárhozat és dölyfös indulatok háborgó vizein, szembefutó hullámzások labilis lázgörbéjén élt, a valóság burkán.” (Ottlik, 1993a. 228.) Ez a valóságvesztés a fokozódó félelem hatására sokkszerü állapothoz vezet: „Ezen a napon állandósult benne az az állapot, hogy egyáltalán semmire sem tud gondolni, csupán forró, vörös és fekete karikák tágulnak-szükülnek a szeme előtt, a naponta megújuló kétségbeesés és tanácstalan zavarodottság félönkívületében." (Ottlik, 1993a. 161.) A háborítatlan nyugalom és szemlélődés perceit a hajnali misék alatt éli át, itt jut levegőhöz, szökését is itt terveli ki. Itt jut el arra a felismerésre, amellyel belső szabadulása elkezdődik: „Valószínü volt, hogy másképp lesz ez, nem az ő feje szerint." (Ottlik, 1993a. 245.) Amint felismeri és elfogadja, hogy a valóság nem az ő elképzelései szerint alakul, rá tud hagyatkozni a lénye mélyén munkáló nagyobb erőre, s ennek köszönhetően megelevenedik a sokkos állapotban megdermedt cselekvőkészsége. Ez erőt és lendületet ad neki a szökéshez, melyet sikeresen végre is hajt, de a valóság tényleg nem az ő feje szerint alakul, mert a megoldást, a kiszabadulás élményét nem a szökés hozza el, hanem a visszatérés. A fogdába kerülve Medve egy darabig a karakteréből fakadó, megszokott stratégiát müködteti: az otthoniakra gondolva érzelmeket gerjeszt magában, és sírni próbál, hogy megkönnyebbüljön. Ez azonban nem a valóság, ezért nem is hoz szabadulást. A valóság azonban itt már „bejelentkezik”: mégpedig józan észlelésekben, tárgyilagos tőmondatokban, s a Nézö-én felismerésében:

Majdnem bosszankodott, hogy nem képes olyan kiadósan sírni, ahogy szeretne. [...] Kit sirat? Mi célból? Ezt, a 345-ös sapkaszámú növendéket siratja? Vagy a Medve Gábor nevü kiskorút? Egyik sem ő. Neki nincs neve, honossága, anyakönyvi adatai, sapkaszáma; ez mind csak szerep, nevetséges komédia. A valóság, a száraz, kézzelfogható valóság az, hogy ő egészen jól érzi magát, mert csak néző. Egész jó meleg van itt. Rosszul világított fogdában ül. Nemsokára behozzák a vacsoráját. (Ottlik, 1993a. 278.)

A lelkiségi szakirodalom a Nagy Én születésének nevezi ezt az ébredéshez hasonló, kivételes pillanatot. Ennek köszönhetően, bár külső életkörülményei nem változnak, Medve élete mégis megváltozik a szökése után, s alakulásnak indul a közösségben betöltött szerepe is. Ennek első, tárgyi-testi jelzése az lesz, amikor máshogy kezdi viselni a katonaiskolai egyenruhához tartozó sapkáját. 
Egészen máshogy formálódik Bébé belső útja. A benne élő, jóhiszemü gyermeki reménykedés, amely a végtelennek tűnő várakozásban táplálja, nem idealizmus, mint Medvénél, hanem már meglévő tapasztalat, amely a gyermekkori szemlélődés, ahogy a Buda nevezi, a „hosszú unalmas délutánok” hozadéka. Mindez az Iskolában higgadtságként, belső nyugalomként, és sajátos gyermeki bölcsességként realizálódik:

Mindegy, hogy százhárom vagy harminchárom, gondoltam, mert ez úgysem mehet így tovább három napig sem. Valaminek történnie kell egykettőre. Szinte kíváncsiság volt bennem, hogy mi lesz, olyan bizonyosra vettem a változást, a fordulatot, mert a lelkem mélyén ismertem jól annak a lágyan hullámzó, sodródó mozgásnak a rejtett törvényeit, ami a létezésemet hordozta. (Ottlik, 1993a. 119.)

Egy későbbi fejezetben ezt olvashatjuk: „Tulajdonképpen sosem hittem benne, hogy a rossz dolgok valóban léteznek. Csak másképp kell értelmezni öket, és nyomban megszünnek." (Ottlik, 1993a. 260-261.) Bébé erőforrása a féltve őrzött belső békéje, ahová mindig vissza tud húzódni: ennek köszönheti gyermeki józanságát, éberségét és alkalmazkodóképességét.

Ahogy Medve a megaláztatást viseli nehezen, és azt, ha félreismerik, és ha nem lehet önmaga, Bébé számára ennek a nyugalomnak az elvesztése jelent veszélyt. Emiatt ö a feszültséget viseli nehezen, illetve a félelem állandósulásából fakadó ürességet és érzelmi dermedtséget, hiszen életeleme a jókedv. Nem véletlen, hogy mélyen megzavarja, amikor elöbb Szeredyvel, majd Medvével törés támad a kapcsolatában, s azokban a jelenetekben, ahol a barátságok végül helyreállnak, éppen a humor kap majd nagy szerepet („Ereklye, piff!”, „Glugy-glugy”). Bébé számára az igazi kihívás, amikor Merényiék beveszik a focicsapatukba, s a helyzet álságossága, hamissága azonnal felborítja a lelki békéjét:

[...] bennem romlani, pusztulni kezdett valami. Olyasmi, ami eddig még soha nem romlott el - a legnehezebb, legnyomorultabb időkben sem -, annyira, hogy eddig nem is tudtam a létezéséről, szakadatlan müködéséről, szükségességéről [...]. Teljesült a vágyam, de ezzel el is pusztult, s vele együtt más is romlani kezdett. Eloszlott a köd, és nyomban romlani kezdett a látásom. Mire megyek ezzel a heves, testközeli boldogsággal, ha nincs már meg hozzá
A regény zárlatában, a mohácsi hajóút elbeszélésébe ágyazva mindkét elbeszéló részéról a belsó út tanulságait összegzô, esszészerú szövegbetétek jelennek meg. Nagyon beszédes, hogy mig Medve a szökése után megszületett magasabb nézópontot, kozmikus távlatot, magyarán a Nézó-ént hangsúlyozza ezekben az elmélkedésekben, addig Bébé az elvesztett

és visszanyert belsó békét, nyugalmat, amely, mint a hajók tôkesúlya, a létezés egészét hordozza szilárdan és rendithetetlenül. Szemléltetésül állitsunk egymás mellé két ilyen összegzó idézetet: Medve: „De hát össze vagyunk kötözve, s még csak nem is úgy, mint a hegymászók vagy a szeretók, nem azzal a részünkkel, amelyiknek neve, honossága, lakcíme van, hanem igazában a nagyobbik részünkkel vagyunk összekötözve, amelyik nézi mindezt." (Ottlik, 1993a. 427.) 
a távlatom? Kikapcsolódott az életem igazi frekvenciája, a lobogás, töltés [...] s a fenyegető érzéstől, hogy az én titkos mélységes nyugalmamat is elveszthetem, névtelen iszonyat fészkelte be magát a mellembe, torkomba, gyomromba, jókedvembe, apró, hegyes kis iszonyat." (Ottlik, 1993a. 380.)

Az idézett részből kitünik, hogy Bébé nem gondolja, hanem tapasztalja, testi szinten érzékeli belső békéje elvesztését és Néző-énje háttérbe szorulását. Éberségét jelzi, hogy azonnal tudatosul benne a veszély, s világosan látja, hogy mit veszít el. S éppen ezért: végül mégsem veszíti el. Amikor Merényiék kiteszik a focicsapatból, a külső történés csupán belső felismerését követi és tükrözi.

A regény zárlatában, a mohácsi hajoút elbeszélésébe ágyazva mindkét elbeszélő részéről a belső út tanulságait összegző, esszészerü szövegbetétek jelennek meg. Nagyon beszédes, hogy míg Medve a szökése után megszületett magasabb nézőpontot, kozmikus távlatot, magyarán a Nézö-ént hangsúlyozza ezekben az elmélkedésekben, addig Bébé az elvesztett és visszanyert belső békét, nyugalmat, amely, mint a hajók tőkesúlya, a létezés egészét hordozza szilárdan és rendíthetetlenül. Szemléltetésül állítsunk egymás mellé két ilyen összegző idézetet: Medve: „De hát össze vagyunk kötözve, s még csak nem is úgy, mint a hegymászók vagy a szeretők, nem azzal a részünkkel, amelyiknek neve, honossága, lakcíme van, hanem igazában a nagyobbik részünkkel vagyunk összekötözve, amelyik nézi mindezt.” (Ottlik, 1993a. 427.) Bébé: „Mintha nem is a hajó remegését éreznénk, hanem belül, saját testünk sejtfalainak, vagy csupán a gondolatainknak, vagy csupán a vágyainknak, emlékeinknek lüktetését, vibrálását, eleven, örök lobogását a nyugalom biztos hajósúlyába zárva." (Ottlik, 1993a. 431.)

\section{Irodalom}

Hermányi Gabriella (2012). Az ingyen mozi motívum előzményei az életmüben. In Füzfa Balázs \& Finta Gábor (szerk.), , ...ami biztosan van ...” - Itt kezdödött a posztmodern? Szombathely: Savaria University Press. 190-200.

Jung, C. G. (1993). Aion. Adalékok a mély-én jelképiségéhez. Budapest: Akadémiai Kiadó.

Mártonffy Marcell (1998). Párhuzamosok találkozása. Vigilia, 11, 857.

Merton, Th. (2008). A szemlélödés magvai. Budapest: Ursus Libris.
Merton, Th. (2011). A belsö tapasztalat. Jegyzetek a szemlélödésröl. Budapest: Ursus Libris.

Ottlik Géza (1993a): Iskola a határon. Budapest: Magvető.

Ottlik Géza (1993b). Buda. Budapest: Európa.

Rohr, R. (2013). Most. Tanuljunk meg látni a misztikusok szemével. Budapest: Ursus Libris.

Rohr, R. (2014). Halhatatlan gyémánt. Igaz Énünk keresése. Budapest: Ursus Libris.

\section{Absztrakt}

Az Iskola a határon címü regényt elemző írások számos értékes kísérletet tettek a szereplők lélekfejlődési ívének felrajzolására, a „belső szabadsághoz” való eljutás lépcsőfokainak számbavételére. Jelen előadás kiindulópontja az az ugrásszerü, racionálisan nem magyarázható szintváltás, vagy inkább szint-áttörés, ami a lelki „kiszabadulás” tapasztalatait Bébé és Medve párhuzamos történeteiben megelőzi. Az a feltevésünk, hogy a belső szabadságra jutás közvetlen kiváltója mindig a jelenlét kivételesen intenzív tapasztalata. Ez a tapasztalat a Szereplő Énből a Néző Énbe való eljutást is jelenti, vagyis radikális nézőpontváltást, s annak a horizontnak a felszabadító kitágulását, amelyen a saját-élet eseményei értelmeződnek - mivel a jelenlét, vagyis a benne megjelenő „van”, a csupasz létezés tapasztalata magasabb rendű realitás, mint az értelmező gondolatok, melyek a jelenlét pillanataiban elhallgatnak. A katonaiskolai traumatikus tapasztalatok folytán értelmét vesztett élet a jelenlét pillanataiban tud új értelmet nyerni. Az előadás a regényben megjelenő jelenlét-élményeket veszi számba, s azt vizsgálja, hogy ez az alapjában megfoghatatlan tapasztalat hogyan, milyen közegekben képes mégis testet ölteni, s nyelvileg kifejeződni. 